\title{
A fragile network: effecting hail insurance in Britain, 1840-1900
}

Pre-print accepted version

Authors:

Samuel Randalls* and James Kneale

*corresponding author

Samuel Randalls, Department of Geography, University College London, Gower Street, London, WC1E 6BT, U.K., s.randalls@ucl.ac.uk

James Kneale, Department of Geography, University College London, Gower Street, London, WC1E 6BT, U.K., j.kneale@ucl.ac.uk

\section{Abstract}

Hail insurance in Britain emerged as a product by and for farming communities, expanding as wheat production rose in the mid-nineteenth century before declining in the latter decades of the century amidst wide-scale conversion from arable to livestock farming. Drawing on detailed research conducted in the remaining archives of the three major hail insurers in this period, we demonstrate the challenges of establishing a new insurance product for farmers. We argue that to make hail insurance effective, the insurance company's central office collated and circulated information, rules and paperwork to enable it to govern farmers, agents and valuers at a distance. Such networks were fragile and required continual maintenance, whether to enhance reputation, manage farmers' requests for new products, enforce rules, or tinker with rates in response to perceived risks and competitive pressures. Conceptualising this emerging insurance business as a fragile network is a useful device demonstrating that paperwork, the governing of actors and personal rival ries are as 
important as broader economic changes in explaining the development of a novel insurance product in this period.

A fragile network: effecting hail insurance in Britain, 1840-1900

\section{Introduction}

Agricultural historians have paid relatively little attention to the role of hail insurance in the nineteenth century and even less to British hail insurance. ${ }^{1}$ Given that less than $10 \%$ of the wheat crop was insured even at the height of the industry, ${ }^{2}$ this is perhaps unsurprising in terms of the crafting of any kind of grand historical narrative. Likewise, hi storians of insurance have tended to focus on life, fire and marine insurance more than agriculturally-specific products like hail. ${ }^{3}$ But we contend that the hail insurance industry nonetheless represents an interesting example of a private insurance for and by farmers that epitomises the challenges of creating new insurance products in this period, advances understandings of power as a sometimes fragile network of actors and reflects the changing fortunes of agriculture through the second half of the nineteenth century. Hail insurance thus represents a productive site for considering the intersection of insurance, agricultural networks of agents, farmers and valuers, and changing appetites for risk in this period. ${ }^{4}$

\footnotetext{
${ }^{1}$ Baker, "Hail as hazard," 20, 36.

2 Stead, "Risk and risk management," 344.

${ }^{3}$ Some examples of histories of insurance include Lobo-Guerrero, "Insuring security"; O'Malley and Roberts, "Governmental conditions"; Alborn, "Regulated lives"; Cockerell and Green, "The British insurance business." ${ }^{4}$ The paper is based on research conducted in three archives. First, the Royal Farmers (including Farmers and General, and Farmers and Gardeners) archive, hereafter 'Royal Farmers', with the archive reference CLC/B/192, London Metropolitan Archives, London, U.K. Second, the County Hail Storm Insurance Company's archive, which will be referred to as 'County', with the archive reference D/EL $A$, miscellaneous collection from the offices of Messrs Longmore, solicitors, of Hertford, with files in the B401-13 series, Hertfordshire County Council archive, Hertford, U.K. Third, the General Hailstorm Company's archived material in Aviva's main corporate archive, Norwich, Norfolk, U.K. Archive reference numbers are provided in each citation.
} 
Storms could be immensely damaging to crops and, to be clear, hail insurance only covered hail risk, not wind or rain. A farmer would have to apply to a local insurance company agent in their nearest town who would complete the paperwork and send it to the head office (in London or a major county town) for approval. Once the fees were paid and agents took their share, the farmer would be covered for a single season for any hail damage to crops that materially affected the quantity of their produce and hence their total economic value within certain limits. Although we do not have definitive data on the farmers involved, internal documents suggest that many were "landed gentry" although the insurance was open to "all classes." ${ }^{5}$ In the event of a hail storm, farmers would have to alert agents in a timely manner. Agents would file the claim with the head office who would ask a surveyor to assess and value the damaged crop or would send a valuer from head office to complete this or to resolve any disputes. If the damage was not found to be caused by hail, the claim would be rejected. The final claim value was dependent on the crop price in the local market town. This brief introduction highlights some important points in demonstrating the networks of relations that supported such contracts: from farmers' declarations about their crops, to agents to manage paperwork and arrange policies, to valuers in adjudicating claims and to a trust in an insurance office located at some distance from the policyholder.

To make hail insurance effective, the insurance company's central office collated and circulated information, rules and paperwork to enable it to 'govern at a distance. ${ }^{\prime 6}$ As other scholarly work, inspired in particular by the work of Bruno Latour has noted, paper, quantification, surveys and statistical techniques enable empire and bureaucracies to work, through re-presenting objects in ways that enable 'the centre' to effect its network of agents. ${ }^{7}$ Such networks require continual maintenance to endure. They do not readily become stabilised, but rather are "rough and ready assemblages", fragile and provisional achievements that are made to work through "tinkering"

\footnotetext{
${ }^{5}$ County, $1^{\text {st }}$ Annual General Meeting report, February 7 1849, MS7247, B407.

${ }^{6}$ Rose and Miller, "Political power," 181.

7 Latour, "Science in action," 219-57; Didier, "Do statistics 'perform'," 307-8; Hull, Documents and bureaucracy," 256-9; Joyce, "The state of freedom," 150.
} 
rather than simple logical design. ${ }^{8}$ Understanding networks or assemblages in this way directs exploration to how they are (re-)shaped in one way rather than another, as 'the centre' experimentally responds to the challenges of governing at a distance through and with sometimes unruly agents. Although in an insurance business history context it is hard to specifically trace the agency of actors for whom archival resources are frequently limited, we can say something about how the central insurance office responded to such agency. ${ }^{9}$ The traces of these are left in the companies' minute books as they had to respond to farmers' requests, agents' bookkeeping inadequacies, crop loss patterns or events that might risk trust in their reputation. The business of hail insurance can therefore be usefully understood as a fragile network, through which the central office effected governing at a distance, but rarely comfortably or totally. More broadly, we suggest that such an argument might be applicable to other objects of enquiry in business history.

Prior to the eighteenth century, hail had largely been conceived as being in the laps of the divine or the supernatural. ${ }^{10}$ Under providential care, there was little that could be done to prevent or manage the impacts of hail, and with shared, communal patterns of land use, such risks would be distributed within agricultural communities. ${ }^{11}$ Hail's geographical specificity limited its impacts on scattered plots. According to Frank Oberholzner, the first agricultural insurance to cover hail was mentioned in notices in Leipzig in 1749 , with prospective cover in kind within local ities, rather than as a monetised system of coverage. ${ }^{12}$ Hail insurance was a novel product in an industry that had been more focused on life, maritime and latterly fire risks. ${ }^{13}$ Insurance and financial products rarely emerged with a sense of inevitability about their economic rationality and prospect; they had to be

\footnotetext{
${ }^{8}$ Law and Ruppert, "The social life," 232.

9 In a life insurance context, Bouk, "How our days," and for fire insurance, O'Malley and Roberts,

"Governmental conditions." Baker and Hahn's "The cotton kings," 73, grapples with the challenge of accounting for non-human agricultural agency.

10 Oberholzner, "From an Act of God," 151.

${ }^{11} \mathrm{McCl}$ oskey, "The open fields," 34-48.

12 Oberholzner, "From an Act of God," 150.

13 Lobo-Guerrero, "Insuring security."
} 
made to work. ${ }^{14}$ As Jonathan Levy has suggested, risk became increasingly productive as a concept through the nineteenth century and American farmers were actively encouraged to consider their activities as an enterprise in which business risks wo uld need to be prudently managed, particularly through insurance. ${ }^{15}$

The principles set out in detail in theory by 1760 , were not taken up in practice until the start of the nineteenth century. In part this might be explained in economic terms, as land use became increasingly individualised and so did farmers' approach to risk management. ${ }^{16}$ But even given this, a lack of social acceptance and a lack of capital restricted the lifespans of many early insurance efforts. ${ }^{17}$ In France, for instance, one mutual society was formed in 1799 , but it operated for just 10 years before being closed down by government for disorderly statutes. ${ }^{18} \mathrm{~A}$ number of regional mutual insurance companies (one estimate suggests 28 new hail companies) were established in the first decades of the nineteenth century providing insurance to farmers at a small advanced sum with premiums varying dependent on the year's total hail damages. ${ }^{19} \mathrm{In}$ Italy, hail insurance policies were developed by the 1830s with experiments using a new formula for assessing remuneration of crop damage. ${ }^{20}$ In Switzerland, early nineteenth century hail insurance frequently failed with companies going into liquidation and only Swiss Hail, established in 1880, survived to the end of the century. ${ }^{21}$ In Britain, hail insurance developed in the 1840 s at a time of increased product innovation in British insurance.$^{22}$ Until this time, British farmers had little access to insurance in general with only a small number of farming crop risks covered by insurers, and that primarily in relation to fire. ${ }^{23}$ The Farmers

\footnotetext{
14 De Goede, "Virture, fortune and faith."

15 Levy, "Freaks of fortune." See also Pietruska, "'Cotton Guessers'."

${ }^{16} \mathrm{McCl}$ oskey, "The open fields," 48-51.

17 Oberholzner, "From an Act of God," 152.

18 Baker, "Hail as hazard," 31.

19 Ibid, 31-32, 35.

${ }^{20}$ Capris de Cigliero, "Saggio sullo stabilimento."

${ }^{21}$ Mauelshagen, "Sharing the risk," 178, 182.

22 Pearson, "Towards an historical model," 243.

23 Insurance against fire risks in farm buil dings dates from 1752, Stead, "Risk and risk management," 344.

Cattle insurance emerged in 1844, al though a number of local mutual clubs had existed from the eighteenth
} 
and General Insurance Company was the first to place serious effort into developing insurance products for farmers in 1839, developing the first hail policies in 1840 based on French experience. ${ }^{24}$ While the business struggled in the initial years, new competitors soon emerged and the 1850 s and 1860s saw rising numbers of hail insurance contracts across the arable heartlands of southern and eastern England throughout the so-called 'golden age' of British agricultural productivity. This is the time associated most with high farming where scientific and technological improvements, as well as considerable investments in drainage, led to an increasing intensity of farming, new methods and greater productivity, all in the context of high wheat prices..$^{25}$ These technologies were often funded by insurance companies too, sometimes on a short-term and flimsy basis, although some companies like The Royal Exchange Assurance recognised that agricultural loans, particularly on drainage projects, were becoming more profitable than mortgages. ${ }^{26}$ Farms also grew larger in this period. ${ }^{27}$ The demise of hail insurance followed from the 1870s onwards not least as farmers struggled in what has been labelled the great agricultural depression during which there was a significant change from arable to livestock (and to a lesser extent market gardening) While crops represented half of UK output in 1870 this had dropped to one third by $1910^{28}$ and wheat prices fell sharply in the 1870 s, not least due to increased imports from America. ${ }^{29}$ This shift was consequential and by the end of the nineteenth century, hail insurance had declined to a fraction of its 1850 s peak.

In this paper, we explore the emergence and development of hail insurance in Britain and argue that a great deal of work was needed to stabilise a network of actors to deliver hail insurance as a potentially necessary risk management product. We contend that paying attention to such networks

century with more clubs established in the nineteenth century, particularly from the 1830s, Matthews, "Cattle clubs," 193, 198.

${ }^{24}$ Stead, "Risk and risk management," 342.

25 Perry, "High farming".

26 Ibid, 368-369.

27 Grigg, "Farm size".

28 Turner, "Output and prices," 45.

${ }^{29}$ Musson, "The great depression," 219. Hunt and Pam, "Managerial failure"; Hunt and Pam, "Responding to agricultural depression." 
enables a lively account of agricultural agency and power in this period, where insurers built fragile power networks that were practical and al ways contingent achievements rather than naturally occurring economicrelations that rationally responded to risk. With this argument, we critique grander claims that the major hail insurers “...demonstrated that financial loss from natural phenomena could be alleviated by insurers using a basis of statisti cal data and prudent reservebuilding. ${ }^{\prime 30}$ Indeed, we claim that understanding the fragile network of hail insurance in the nineteenth century is crucial to developing accounts of the "grubby reality" of new businesses. ${ }^{31}$ First we begin by outlining the development of hail insurance in the early 1840 s, before exploring in more detail various factors that shaped the main years of the industry from the late 1840 s to the late 1870s.

\section{Tinkering with hail insurance in Britain}

Hail insurance developed through tinkering. Eminent agriculturalists convened a board meeting for a new Farmers and General Fire and Life Insurance and Loan and Annuity Company in November 1839. These directors, as they became with the formation of the company, included Joseph Rogerson (as chair), William Shaw, Dr Joseph Blackstone, and William Youatt. ${ }^{32}$ They were connected through agricultural networks not least through the publication of the scientific Mark Lane Express and Agricultural Journal. William Shaw was the editor of this magazine from soon after its founding in 1832 until 1852, while Joseph Rogerson was also involved not least through his capacity as a printer. ${ }^{33}$ Shaw promoted agricultural improvement and the use of science to improve technological efficiency. He founded the London Farmer's Club in 1843 and desired other local areas to follow suit. ${ }^{34} \mathrm{He}$ was also a founder of the English, later Royal, Agricultural Society in 1839 at a time of great

\footnotetext{
${ }^{30}$ Cockerell and Green, "The British insurance business," 84.

${ }^{31}$ Baker and Hahn, "The cotton kings," 152.

32 Royal Farmers, Minute book 1, 1839-1841, MS14989/001.

33 Clarke, "Shaw, William"; Goddard, "The development and influence," 130.

${ }^{34}$ Clarke, "Shaw, William"; Goddard, "The development and influence," 127.
} 
controversy over the corn laws though the organisation resolutely avoided getting entangled in political debates. ${ }^{35}$ In the 1840s it became involved in supporting local farmers' clubs and became particularly well-known more widely through the establishment of an annual agricultural show. ${ }^{36}$ William Youatt had important farming connections too as the first editor of the Veterinarian magazine. ${ }^{37}$ The Farmers and General insurance company thus emerged through a network of elite agricultural actors who had extensive knowledge of farming and strong personal connections. This can be seen in the kinds of agents they recruited for the business including the famous veterinarian William Karkeek, appointed as agent for Truro in $1840^{38}$ and local bankers like James Chesshyre, appointed that same year for Hertford and someone who was noted for being busy with farming clients on market days, ${ }^{39}$ who later went on to found a rival hail insurance company.

Farmers and General issued adverts in late 1839 and early 1840 in The Standard and many local papers to emphasise its position as a fire and life insurance office specifically forfarmers, who they considered had a poor deal from other insurers given that they were both better life prospects (i.e. longer-lived) and had lower fire risks due to low density buildings. ${ }^{40}$ As an advert in in Trewmans Exeter Flying Post in January 1840 stated; they would "give to the farmers that which they have long desired, an insurance company of their own, conducted by their leading friends, devoted to their leading interests, and ready to relieve their temporary wants." ${ }^{41}$ They formally commenced business on the $25^{\text {th }}$ March 1840.

As early as April and May 1840, the Board received a number of requests by letter from farmers for insurance from storms and tempests..$^{42}$ Agreeing that this was an important issue for the farmers,

\footnotetext{
${ }^{35}$ Cox, Lowe and Winter, "The origins and early development," 31.

${ }^{36}$ Miskell, "Putting on a show."

${ }^{37}$ Goddard, "The development and influence," 117.

${ }^{38}$ Royal Farmers, Minute book 1, 1839-1841, MS14989/001.

${ }^{39}$ Royal Farmers, Board meeting report, March 2 1875, MS14991.

${ }^{40}$ Advert in The Standard, 6 November 1839, 4799, 1. Royal Farmers, Minute book 1, 1839-1841, MS14989/001.

${ }^{41}$ Advert in Trewman's Exeter Flying Post, January 9 1840, LXXVIII, 3868.

42 Royal Farmers, Minute book 1, 1839-1841, MS14989/001.
} 
the directors resolved that they would insure standing corn against hail damage at a rate of $6 \mathrm{~d}$ an acre for the first year, $2 \mathrm{~d}$ a year thereafter. The board permitted themselves the freedom to change rates if experience found these to be too high or low. They also set a maximum crop claim limit per acre. ${ }^{43}$ Yet Farmers and General's appetite for risk at this time appeared somewhat limited and the lack of British hail experience worrying as, in May 1840, they decided to open a separate hail fund for a trial period of "four complete harvests; the fund for losses to be formed entire ly of the premiums paid which shall be kept inviolate for such purpose." ${ }^{44}$ It was to be an experiment with any remaining money in 1843 to be distributed to the insured if they discontinued the business, or else placed in a fund for the general stock of the company if it was continued. ${ }^{45}$ In other words, Farmers and General agreed that the hail business would operate completely independently of the fire and life business, with all risks borne solely within the hail business, an approach that was solidified under the creation of a new company Farmers and Gardeners in late 1841 and formally constituted in February $1842 .{ }^{46}$ Both businesses, however, would use the same network of agents and the directors would be free to promote hail insurance as long as it encouraged uptake of fire and life business too. ${ }^{47}$ Partitioning out risky insurance groups into separate companies was also practiced in life assurance, for instance Standard Life's placement of overseas residence policies within Colonial Standard. ${ }^{48}$ Ironically, it was the hail business that proved most profitable for Farmers and General

There is some doubt, however, over when the first hail insurance policies were actually issued. In a review in 1861, John Reddish, who had been appointed secretary to Farmers and General in 1853, noted that Farmers and General issued policies in 1840 on produce of 14,801 acres with a total

\footnotetext{
43 Ibid.

44 Ibid.

45 Ibid. See also Stead, "Risk and risk management," 342.

${ }^{46}$ Royal Farmers, Farmers and Gardeners Hail Storm Insurance Company Minute book, 1842 -1843, MS14988.

${ }^{47}$ Royal Farmers, Minute book 2, 1841-1842, MS14989/002.

48 Kneale and Randalls, "Imagined geographies."
} 
policy value of $£ 155,873$ and transacted hail business again in $1841 .{ }^{49} \mathrm{He}$ could find no evidence in the accounts that policies had ever been paid, a fact that has led subsequent commentators to doubt that any policies were formal ised before $1842 .{ }^{50}$ It is impossible to know for sure, however, because the company clearly divided the hail and general business accounts, implying that hail insurance was de facto conducted and recorded in separate ledgers. ${ }^{51}$ It was only in 1842 when the business was hived off to Farmers and Gardeners that proper records were kept and these reveal that the company signed off on 689 policies with total premiums of $£ 934$, paying out $£ 108$ on 4 policies..$^{52}$

As the company experimented with hail insurance, the directors tried to acquire knowledge of the risks. In June 1842 they wrote to agents to ascertain the frequency of hail storms in particular farms and districts from their recent experience..$^{53}$ They rejected policies on products like onion seed as they had insufficient risk knowledge..$^{54}$ They asked experienced directors to provide surveys of crop losses in the absence of experienced and trusted local valuers. ${ }^{55}$ Hail insurance had to be made to work effectively, through tinkering, learning and dealing with challenges as they arose. The four season review took place towards the end of 1843 . This had been a very expensive year to be in the hail business with a particularly severe August hailstorm ${ }^{56}$ leading to the largest amount of claims on

\footnotetext{
${ }^{49}$ Royal Farmers, Correspondence from John Reddish to the Royal Farmers Board of Directors, March 301861 , copied into the Royal Farmers Board Report 1861, MS14991. With regard to 1841, Reddish stated that he wrote to a Mr Nockolds that: "We have not at present had any losses by Hail Storms" and to a Mr Lavington that: "We have already renewed our policies on the greater portion of our last years business ... and at a premium of 2 /cent have affected insurances to an amount exceeding $£ 150,000$."

50 Stead, "Risk and risk management," 342.

${ }^{51}$ Royal Farmers, Minute book 1, 1839-1841, MS14989/001.

52 The number of policies comes from Royal Farmers, Farmers and Gardeners Hail Storm Insurance Company Minute book, 1842-1843, MS14988. The value of policies and pay-outs comes from Stead, "Risk and risk management," 343.

${ }^{53}$ Royal Farmers, Farmers and Gardeners Hail Storm Insurance Company Minute book, 1842 -1843, MS14988. Although we cannot be sure whether agents accessed meteorological instruments, it's more likely that agents responded to the request based on their and farmers' experience, as while there was folk prediction of weather for agriculture, instrumental meteorology was less developed, Anderson "Predicting the weather", 44,68 .

54 Ibid.

55 Ibid.

${ }^{56}$ Webb and Elsom, "The great hailstorm."
} 
policies until 1859 (when premiums were considerably higher). On $£ 236$ of premiums they paid out $£ 5,522$ in claims.$^{57}$ This was a sure route to bankruptcy, but Farmers and General considered the overall experiment to be a success despite the year's results. If anything, such a signi ficant hailstorm may have galvanised interest from farmers in having such cover, not least as it looked economically productive for them.

In December 1843, Famers and Gardeners business book was offered back to the Farmers and General, initially at an agreed price of $£ 6,500 .{ }^{58}$ The directors of Farmers and General agreed that they would continue to provide hailstorm insurance as originally desired and that it was "expedient that the offer of the Farmers and Gardeners Hail Storm Insurance Company be accepted" particularly in light of the fact that the Norwich Union Insurance Office was setting up a new hail office, the General. ${ }^{59}$ Fear of competition proved a catalysing factor. Not all shareholders were as smitten as the directors however and after a dispute led by a Mr Workman, the $£ 6,500$ was later designated as a payment that would be repaid solely out of future hail premiums. ${ }^{60} \mathrm{Hail}$ as an experimental product could not undermine the sanctity of the fire and life business. Farmers and General had also learnt from their experience of this season and they changed the insurance rates accordingly. The basis for premiums shifted from a percentage of crop value to a per acreage rate, and they charged wheat, barley and peas at $6 \mathrm{~d}$ per acre, potatoes, beans, oats and turni ps at $4 \mathrm{~d}$ per acre, with seeds by special agreement. ${ }^{61}$ Despite a significant loss, hail remained a viable insurance product as it was supported by agricultural directors that were convinced of its merits as well as a fear that a competitor might seize the initiative in an emerging market. The agricultural experts were entrepreneurial in theirvision.

\footnotetext{
57 Royal Farmers, Farmers and Gardeners Hail Storm Insurance Company Minute book, 1842 -1843, MS14988.

${ }^{58}$ Royal Farmers, Minute book 4, 1843-1844, MS14989/004.

59 Ibid.

60 Ibid.

${ }^{61}$ Royal Farmers, Farmers and Gardeners Hail Storm Insurance Company Minute book, 1842 -1843, MS14988.
} 
This account of the emergence of hail insurance illuminates a number of important factors that were central to shaping the development of the industry. First the re needed to be a trust from farmers and agents towards this new insurance company ensuring its reputation at a time of frequent insurance failure. Second the pricing of the risk was unknown and a significant loss that would have collapsed many emergent insurance concerns, had to be overcome with a certain degree of persuasion by company directors to put the business on an even keel. Third, the network of paperwork and payments between farmers, agents, valuers and head office created a fragile network that could and at times did break down. Not least controlling such a network proved challenging from both head office and agent perspectives. Fourth, the fear of competition becamea spur to Farmers and General's efforts to remain at the centre of the agricultural network built on friendship and comradeship with farmers.

Hail insurance expanded rapidly from the 1840s and reached a nineteenth century economic peak in the 'heyday' of arable agriculture from the 1850s through to the early 1870s (Figure 1). Competitors emerged, most significantly the General and the County. Claims on policies varied considerably from year to year (Figure 2). To provide qualitative insight into this quantitative evidence, we explore how hail insurers stabilised and managed the network of actors in support of these products from the mid-1840s after the initial product formulation had been completed, and some of the challenges they faced in maintaining such a fragile power, not least in the face of developing competition for the pioneering Farmers and General.

\section{Managing the hail network}

\section{Maintaining reputation}

As part of building a successful new insurance business, the product had to be made to work and be believed in. The Farmers and General were particularly keen to ensure trust in their reputation and 
secured the support of a large number of eminent, 'responsible' country aristocrats and gentlemen to be honorary directors. ${ }^{62}$ The granting of a Royal Charter in 1843 bestowed further prestige as insurance companies were sometimes rejected for royal charters, depending on their ability to prove their low level of risk or that they provided for provident men in need of support. ${ }^{63}$ The new title 'Royal Farmers and General, Fire and Life Insurance, Loan and Annuity Institution' was adopted immediately thereafter (and we will refer to the company as Royal Farmers from hereon). The same year, they tried to professionalize their business approach, with a new rate structure that priced crops differentially, limited claim amounts of produce per acre (e.g. wheat was 5 quarters per acre in April 1844), and instituted rules on the required paperwork and timeliness of reporting that would enable them to govern at a distance ${ }^{64}$ At the same time, it was important that policyholders believed that the company would pay out, so minor indiscretions or breaches in paperwork were 'exceptionally' but not uncommonly overlooked. Building goodwill and trust to encourage a renewal of policies was vital. One example is a claim from a Mr Bluff, which was entertained despite his policy not reaching central office in time. ${ }^{65}$ Discretion was applied where it enabled amity and policy renewals.

The emergence of the General Hail Storm Insurance Society in 1843, established by C. S. Gilman in Norwich, Norfolk, gave Royal Farmers even more reason to protect their reputation. An advert in the Illustrated London News in 1844 emphasised the capital, experience and security of the Royal Farmers as compared to their new rival. While the General might charge lower rates, the Royal Farmers experience had taught them that low rates would end in business failureand that it was better to charge more and redistribute that money to policy-holders later when hail damage had

\footnotetext{
${ }^{62}$ Adverts for the company provided an extensive list of honorary directors including the Dukes of Bedford and Rutland, five Earls, two Viscounts and three Lords, as well as el even M.P.'s. Advert in Illustrated London News, April 6 1844, 101, 224.

${ }^{63}$ Lobo-Guerrero, "Insuring security," 49. The Farmers and General royal charter was granted in August 1843 through the efforts of one of their agents, a Mr Bell of Maidenhead, to whom they paid 10 guineas for his effort. Royal Farmers, Minute book 4, 1843-1844, MS14989/004.

${ }^{64}$ Royal Farmers, Minute book 4, 1843-1844, MS14989/004.

${ }^{65}$ Royal Farmers, Minute book 15b, 1859-1864, MS14989/016.
} 
been lower than expected. They also reminded readers that they were the first company to protect against the calamity of hail and that they believed "they have a claim upon the grateful feelings of the British farmers" to respond. ${ }^{66}$

Despite internally having seen the hail business as a risky proposition, in need of clear demarcation from the life and fire business, within 4 years, hail was paraded as a product of significant experience within the company and worthy of the accolades of the farming communities. They further established their credentials as the real friends of the farming communities in the face of competition by sending a copy of 'Van Thaer's Principles of Agriculture' edited by director William Shaw to each Farmers Club in Britain, along with a bound-in copy of the company prospectus. ${ }^{67}$ These must have been well-received as they ordered more copies of the book in November and, for instance, the Bromsgrove Farmers Club noted receipt of the book with thanks in the Berrow's Worcester Journal, a clipping of which was sent to head office in March $1845 .{ }^{68}$

The reputation of the Royal Farmers had to be maintained. Despite some professionalization, Royal Farmers' accounting remained haphazard as they struggled to get agents to provide receipts on formal paper, there were questions about which policies had actually been paid and corrections had to be made e.g. adjusting the over-inflated premium figures for 1846 where some farmers never actually received policies. ${ }^{69}$ Internal operational issues also affected the company, though scandals were wherever possible kept from public eye. In 1845 the board discovered that a former cashier of the business, John Bevis, had likely embezzled $f 1,169: 11: 3$. With too little evidence for prosecution, however, and an acknowledgement of weak oversight from the managing director, they had to ask the directors of the company to buy shares to replace the lost money and put in place a new system

\footnotetext{
${ }^{66}$ Advert in Illustrated London News, 6 April 1844, 101, 224.

${ }^{67}$ Royal Farmers, Minute book 4, 1843-1844, MS14989/004.

${ }^{68}$ Royal Farmers, Minute book 5, 1844, MS14989/005. Column by J. Macgregor in Berrow's Worcester Journal, 6 March 1845, 7423.

${ }^{69}$ Royal Farmers, Correspondence from John Reddish to the Royal Farmers Board of Directors, March 301861 , copied into the Royal Farmers Board Report 1861, MS14991.
} 
of checks. ${ }^{70}$ By replacing the capital in this fashion they secured the business accounts, engaged in professionalising their office activities through stricter rules and avoided a possible public reputational crisis.

A worse scandal was to follow in 1852 when William Shaw disappeared to Australia to escape bankruptcy at home in other business interests, without tell ing his wife or the Royal Farmers directors. ${ }^{71}$ In fact, his unannounced absence occasioned a stern letter to be sent to his home after the $9^{\text {th }}$ of November board meeting setting out the "considerable inconvenience" he had given the firm. ${ }^{72}$ Before a reply was received (from his wife), they received a letter from Shaw on the $13^{\text {th }}$ November but dating from October $4^{\text {th }}$ that he felt entitled to take some holiday and that he thought the others could take care of the business in his absence. A second letter from Shaw also dated the $4^{\text {th }}$ October further set out to Mr Sneddle that his years in the office entitled him to a break and noted that before the letter would arrive, he would al ready be on the ship. ${ }^{73} \mathrm{At}$ the start of December they revoked Shaw's role as Managing Director. They re-assured their business contacts by stating that they were confident the company would not suffer too much given the expertise and experience in the company. ${ }^{74}$

Managing internal business affairs was a critical part of running an insurance concern and while these are somewhat limited in import on the actual operation of the business, they nonetheless show that we must be cautious of treating insurers as businesses with immense power to make farmers do as they pleased. There was an internal fragility in maintaining a small, emerging insurance business in the mid-nineteenth century. Solicitors became involved on a number of occasions to deal with claims against hail insurance companies with evidence concerning cases with

\footnotetext{
${ }^{70}$ Royal Farmers, Minute book 5, 1844, MS14989/005. Royal Farmers, Minute book 6, 1844 -1845, MS14989/006.

${ }^{71}$ Clarke, "Shaw, William."

72 Minute book 13, 1851-1852, MS14989/013.

73 Ibid.

74 Ibid.
} 
disgruntled employees, agents and policyholders. Perhaps the most fascinating case is the aforementioned clerk John Bevis, sacked in October 1844 for poor attendance and neglect of duties, but who sued the company over his dismissal. In January 1845 solicitors advised the company to settle out of court with him; his embezzlement was only uncovered months later. ${ }^{75}$ Reputation took work to build and maintain, and it was critical in the context of an emerging competition for farmers business within the industry.

\section{Universalor competitive pricing amidst seasonal renewals}

Maintaining reputation did not extend to maintaining the same prices and procedures each year and insurers were perfectly comfortable with tinkering with the prices of hail insurance contracts. At various times, the different hail insurance companies worked together to agree prices and at other times agreed prices fell apart in the interests of competition. Rather than this being a story of increasing calculations based on loss data ${ }^{76}$ there was more in the way of a secretive and informal pricing that relied perhaps more on an idea of 'cumulative dangerousness' than the rigorous actuarialism seen in life assurance. ${ }^{77}$ In a seasonal product like hail, with an annual renewal cycle (see Figure 3), adjusting prices annually became a possible strategy, but one that enabled competitors to quickly seize market share from each other.

At an early stage of the emergence of the rival General office, the Royal Farmers board attempted to agree rates with them. In March 1846, for instance, Mr Tuxford was dispatched on three journeys to

\footnotetext{
75 Royal Farmers, Minute book 5, 1844, MS14989/005. Royal Farmers, Minute book 6, 1844-1845, MS14989/006. Another claim concerned unpaid distribution and postage fees for prospectuses for the County and led to a Writ of Summons being issued against Chesshyre. County, Writ of Summons, December 211852 , B411. Solicitors also worked to defend the companies, becoming involved with disgruntled shareholders and directors, Royal Farmers, Minute book 14, 1852-1855, MS14989/014 and Minute book 18, 1874-1878, MS14989/019, unhappy policyholders, Royal Farmers, Minute book 9, 1847-1848, MS14989/009, agents that were injured while ins pecting claims, Royal Farmers, Minute book 14, 1852-1855, MS14989/014, and insolvent agents, Royal Farmers, Minute book 16, 1864-1869, MS14989/017 and Minute book 17, 1869-1874, MS14989/018.

${ }^{76} \mathrm{Cf}$ : Oberholzner, "From an Act of God," 152. Cockerell and Green, "The British insurance business," 84.

77 O’Malley and Roberts, "Governmental conditions," 256. Porter, "Trust in numbers," 104-106.
} 
Norwich to discuss and agree rates as well as the process and resolution of any disputes in the valuation of damage. ${ }^{78}$ They even agreed that over the coming years they would share data on their agent's proposals to enable them to identify any agents with a high number of policyholders making claims (see section 3.3). Reaction to losses could be swift. Royal Farmers altered rates for rye seeds in May 1846 after Mr Gilman wrote to them regarding recent price changes they had enacted at the General fearing exposure to agents with contracts on rye seeds. ${ }^{79}$ Another company's experience was therefore used to alter the agreed rates. Indeed in December that year, Mr Tuxford was sent to Norwich again to agree rates for the following season that would see "as great an increase of rates as possible" to protect against future risks, which was both about recent claims but also concern for the rising price of corn and other crops. ${ }^{80}$ The 1847 rates would indeed be much higher, and with agreed pricing, reputation and local networks would determine the insurance company's prospects.

The emergence of a third competitor in late 1847, however, swiftly challenged such an enterprise. James Chessyre, manager of the London and County bank in Hertford and formerly an agent for Royal Farmers, established a new company, the County, in Hertford at the request of a number of "large and influential farmers." ${ }^{81}$ While Chesshyre recognised the innovation of Royal Farmers in establishing hail insurance, he claimed his important role within this. Addressing the 1848 AGM of the County he "...was happy to say that the first hail-storm company [Royal Farmers] was promoted by himself" after a conversation over dinner at his house where a farmer discussed the loss from a severe hailstorm and "suggested an office for insuring against such risks. Mr Shaw caught at the idea, drew up a prospectus, sent it down to him for his approval, and that was the origin of the first hail-storm company in existence." 82 Calling a meeting for the Salisbury Arms in Hertford at 3:30pm

\footnotetext{
${ }^{78}$ Royal Farmers, Minute book 7, 1845-1846, MS14989/007.

79 Ibid.

${ }^{80}$ Royal Farmers, Minute book 8, 1846-1847, MS14989/008.

${ }^{81}$ Circular from Thomas Sworder and James Chess hyre, December 16 1847, County, B405, 7264/85.

82 Herts Guardian, February 1868, a clipping of which is included in Reddish's notebook. Royal Farmers, John Reddish's notebook, MS14999A.
} 
on the $18^{\text {th }}$ December 1847, Chesshyre with a solicitor Thomas Sworder invited farmers and agents to attend to appoint a provisional committee. ${ }^{83}$

The new hail storm company would feed off the "much dissatisfaction" that they were convinced had been felt about the terms and conditions offered by other companies, particularly in the face of the considerable price rises for the 1847 season. ${ }^{84}$ Chesshyre felt that "many farmers [are] most anxious to avail themselves of such a desirable security" but had been prevented from doing so and they intended to adopt the rates of Farmers and General in the 1844-6 period, the years "of their greatest success", namely $6 \mathrm{~d}$ per acre, citing the fact that the insurance was "so profitable" and that they had repaid all the capital back to Farmers and Gardeners much faster than they had expected. ${ }^{85}$ Hail insurance, in the County's view, could be both profitable and yet well priced for farmers. In late December 1847 they planned to advertise for agents across the Home Counties, opening an office in Market Place in Hertford so farmers could get their insurance "without the trouble of walking a hundred yards." ${ }^{86}$ Their 1848 season started late, however, due to problems with formalising the company deed. ${ }^{87}$ They would nonetheless be the competitor that would undermine the cosy pricing agreement between Royal Farmers and General that had, in theirview, led to increased rates beyond what farmers could afford.

The Royal Farmers were well aware of the plans for the new company and discussed the news at a board meeting in February $1848{ }^{88}$ They were initially more concerned with agreeing rates with the General for the coming season "with a view to the two offices acting in consort" again. ${ }^{89}$ Indeed Mr Gilman visited London and they agreed to raise rates for wheat and other grains. Then in May 1848 we see the first evidence that the County were starting to challenge this pricing agreement. One

\footnotetext{
${ }^{83}$ Circular from Thomas Sworder and James Chesshyre, December 16 1847, County, B405, 7264/85.

84 Ibid.

${ }^{85}$ County, Correspondence from James Chesshyre to Thomas Sworder, December 22 1847, B405, 7264/84.

${ }^{86}$ County, Correspondence from James Chesshyre to Thomas Sworder, December 27 1847, B405, 7264/81.

${ }^{87}$ County, $1^{\text {st }}$ Annual General Meeting report, February 7 1849, MS7247, B407.

${ }^{88}$ Royal Farmers, Minute book 9, 1847-1848, MS14989/009.

89 Ibid.
} 
agent from St Ives, Cambridgeshire, for instance, wrote in to complain that persons who had previously insured crops were preferring to insure in the County instead. ${ }^{90}$ At a later board meeting on the $19^{\text {th }}$ of June, the managing director reported that he had received several more letters complaining about the rates and conditions and "expressing apprehension that business would be materially reduced in consequence. ${ }^{\prime 11}$ Indeed the figures show the premium income of Royal Farmers declined from $£ 7,504$ in 1847 to $£ 2,532$ in 1848 (Figure 1).

These pricing dilemmas continued over the coming years. From 1849-1852, while the County tried to undercut with lower premiums, Royal Farmers and the General worked together with their only response to the County being to allow some discretion for Managing Directors to alter premiums for seeds as particular cases required.$^{92} \operatorname{In} 1853$, the County initiated attempts to agree rates, but due to lengthy discussions, Royal Farmers approved their hail rates to prevent any delay in issuing policies and it was the County and the General that adopted agreed rates. ${ }^{93} \ln 1854$, Royal Farmers sided with the County against the General. ${ }^{94}$ The following year the final major new competitor emerged, the Midland Counties Fire and Life and Hail Storm Insurance Company, based in Lincoln. A prospectus was published in The Leicester Chronicle in June 1854 detailing its $f 1$ million capital, its committee and the chairman William Rudgard, who headed up the Lincolnshire Fire Office that had been established in 1851. Its success with fire prompted them to offer life and, in 1855 , hail. ${ }^{95}$ The discussions about agreed rates now became four-way.

Other smaller rivals also emerged and these proved consequential to pricing decisions. Indeed in 1855 it was Mr Gilman of the General that wanted to reduce rates, something the Royal Farmers

\footnotetext{
90 Ibid.

${ }^{91}$ Royal Farmers, Minute book 10, 1848, MS14989/010.

92 Royal Farmers, Minute book 11, 1848-1850, MS14989/011.

93 Royal Farmers, Minute book 14, 1852-1855, MS14989/014.

94 Ibid.

95 Prospectus of the Midland Counties Fire and Life and Hail Storm Insurance Company, The Leicester Chronicle, June 17 1854, 2273. The Midland's archives remain uncatalogued and inaccessible within Liverpool Council's Archives.
} 
assented to only "under the pressure of increased competition." ${ }^{96}$ It appears likely that the threat to the General was another Norwich based hail company, the National Economic Hail Storm Assurance Company, which had emerged in the same year and would be competing for the same local business. Perhaps unsurprisingly it was taken over by the General just two years later (see Table 1). Not all competition invoked such strategies, however. Mr Longstaffe writing to the Royal Farmers from Andover in 1855 urged the directors to reduce rates to match a locally-forming county hail storm society but his request was flatly declined. ${ }^{97}$

Competition mattered, but so did an increasing focus on calculating the hail risks. In 1859 John Reddish, secretary of Royal Farmers, constructed tables of premiums and losses to compare the rates of different companies updating these in subsequent years for the board meetings. ${ }^{98}$ In his five years in the company, he had enforced a stronger accounting system for polici es and crafted numerous figures and tables to report various aspects of the insurance business. He was a 'bean counter' whose bookkeeping enabled him to spot loss patterns amongst agents and counties. Reddish was methodical in calculating loss ratios for particular agents, counties and crops. While concerns about losses had been noted before then, these logs enabled Royal Farmers to engage with the County, the General and the Midland to compare their notes on agents and areas to construct, for the first time, a sense of hail risk (though, as we'll show, loss ratios were not definitive in shaping business strategy). To explore the question of what constituted 'hail risk', we must first turn to an area of significant risk within the business - the network of actors, the agents and valuers, that enabled these insurance companies to sell and value hail insurance policies and claims across the extent of the country.

\footnotetext{
${ }^{96}$ Royal Farmers, Minute book 15a, 1855-1859, MS14989/015.

97 Ibid.

${ }^{98}$ Royal Farmers, Board Report April 1859, MS14991. Royal Farmers, John Reddish's notebook, MS14999A.
} 


\section{Governing valuers and agents}

Companies hired local agents in market towns across the country who would represent the business, cajole local farmers into buying policies, and process all the relevant paperwork. They were not recruited in a systematic geographical way and some areas were far more densely networked than others. ${ }^{99}$ Agents often advertised a wide range of insurance products for their company, garnering commissions on policies. An agent's book for Royal Farmers, dating from 1858, showed that agents were paid $7.5 \%$ on the premium for hail, with an additional $2.5 \%$ if it was paid on time. ${ }^{100}$ Agents were frequently eminent and socially networked people in the community, whether bank managers, veterinary surgeons, solicitors, surveyors or merchants. Agents were a worrisome source of risk for insurers in terms of their possible deceit, paperwork failures and choice of policyholders, so they were carefully monitored and were expected to follow the instructions and forms provided to guide them as to acceptable policies and risks. ${ }^{101}$ This standardised paperwork enabled the office to govem these agents and policyholders at a distance. ${ }^{102}$ While agents or farmers may have disagreed with particular rules, policyholders would usually have to abide by them and apply to the central office for exceptions or new risk coverage. As we have already noted, agents wrote to the companies regarding premium rates and sometimes arguing for rate reductions on behalf of local farmers. They also regularly checked the rules, for instance, one agent enquired to Royal Farmers in May 1847 about how they would price smallholders insurance - an added extra charge was agreed in cases where premiums were less than $20 \mathrm{~d} .{ }^{103}$ On behalf of individual farmers, agents enquired as to the price of particular crops that were not directly covered in the instructions distributed by the head office. In May and June 1845, Royal Farmers received requests for prices for turnips, mustard seeds,

\footnotetext{
${ }^{99}$ As with Didier's agricultural survey reporters, it required agents with the time and energy to invest in the required paperwork, but representativeness was far less of a concern for insurers than statistical surveys. Didier, "Sampling and democracy," 430.

${ }^{100}$ Royal Farmers, Instructions for Agents, 1858, MS14997/4.

101 Alborn, "Regulated lives."

102 Bouk, "How our days became numbered"; Zakim, "Accounting for capitalism."

103 Royal Farmers, Minute book 8, 1846-1847, MS14989/008.
} 
buck wheat, mustard seeds and caraway seeds. ${ }^{104}$ Rates were based on what the Board considered to be equivalent types of products, again a form of experimental response which would be amended as experience (and competition) dictated.

As well as tinkering with new products, there were other fragilities in this network. In 1854, the Royal Farmers board became concerned with the work of agents in the Cambridge office and interrogated the transactions of two agents, Mr Barlow and Mr Swan, in some detail. ${ }^{105}$ The report on this office, discussed in September 1854 and encompassing fire as well as hail risks, showed that Mr Swan's agency had lost $£ 6,211: 19: 11$ across fire and hail in 7 years, compared to a profit for Mr Barlow's agency. The Board discussed whether to close Swan's agency, but noting that the vast majority of losses were in Cottenham fire policies, they entered an agreement on the specific risks in that village. ${ }^{106}$ Swan was clearly not best pleased and contested the change in rates using sketches to demonstrate the risks. ${ }^{107}$ The Royal Farmers weren't moved, even when they noted in December that Swan was known to have travelled to London to negotiate lower rates with other insurance companies. ${ }^{108}$ It seems that he nonetheless continued to transact business with Royal Farmers.

As well as agents, valuers played an important role for the head office too as they checked claims and valued the loss on behalf of the company. Insurers tinkered with their processes to maintain trust in this fragile network. Royal Farmers would not allow agents to value claims and it appears that agents complained about the strict procedures given that other companies may have permitted them to do so. ${ }^{109}$ Valuation was a challenging process for a head office as the level of financial compensation was based on the crop acreage and the "average price of the nearest market town, on

\footnotetext{
104 Royal Farmers, Minute book 6, 1844-1845, MS14989/006.

105 Royal Farmers, Minute book 14, 1852-1855, MS14989/014.

106 Ibid.

107 Ibid.

108 Ibid.

${ }^{109}$ Royal Farmers, Correspondence from John Reddish to the Royal Farmers Board of Directors, 30 March 1861, copied into the Royal Farmers Board Report 1861, MS14991.
} 
the market day previous to the occurrence of the loss." ${ }^{110}$ In the early years of hail insurance, Royal Farmers sent valuers from head office, most especially Thom as Rogerson who was appointed as Superintendent of the Hail Department in November 1844, to adjudicate and value claims. ${ }^{111}$ Contested claims were not uncommon, both on the grounds of the crop value and as to whether hail had actually caused the damage. Valuations of loss were noted in the minute books, one of the first examples being in October 1844, when there was a disagreement about the value of a claim that was settled in a split between what the insured's valuation suggested and what the company valuation suggested. ${ }^{112}$ Another example, in August 1846, further demonstrated that head office did not always win, with Royal Farmers 'exceptionally' agreeing to pay more than Mr Rogerson's valuation suggested, though they made it clear this was not to be made an example. ${ }^{113}$ If valuation could be tricky due to the variability of local pricing, ascertaining whether crops had actually been damaged by hail was a speciality for experts within the hail insurers. That did not mean local valuers always followed the rules or understood the distinctions (and there may have been fraudulent claims too). In summer 1845, the minute books of Royal Farmers record several examples of refused payments to farmers because the damage was not caused by hail. In one example, a claimaint by the name of Mr Hesell, of Wootton Bassett, was explicitly to "be informed that the straw of the crops must be actually split by hail to constitute a recognisable claim for compensation." ${ }^{114}$ The company had to re-iterate its position to valuers on a number of occasions. Reddish in writing to a valuer on the $3^{\text {rd }}$ of August 1860 gave explicit instructions: "We do not insure against loss by Wind, Rain, Blight \&C. and it is very important to avoid admitting as a loss by hail, any injury which is attributable to either. Hail leaves clear evidence in the bruised, broken, cut and split straws. The directors have found that a great deal of experience in the examination of crops

\footnotetext{
${ }^{110}$ Royal Farmers, Minute book 6, 1844-1845, MS14989/006.

111 Ibid.

112 Ibid.

113 Royal Farmers, Minute book 8, 1846-1847, MS14989/008.

${ }^{114}$ Royal Farmers, Minute book 6, 1844-1845, MS14989/006.
} 
supposed to have been damaged by Hail Storms is necessary, to enable a Valuer to speak with confidence on the question of cause and extent of damage; and have, when a new Valuer has been employed, taken an opportunity to send an old Valuer to assist or to follow him." ${ }^{115}$ Controlling valuers took time and effort; it was not a simple task to run an in surance company that relied on local expertise and networks to support it, especially given that agents might have personal connections to those insured. ${ }^{116}$ Governing at a distance required a performance of expertise from the centre while enabling tacit and local knowledge to co-exist.

Valuers not only checked for hail damage, but they al so policed other rules of the insurance. Although not couched in terms of moral hazard, not least as hail insurance is unlikely to have resulted in actions that would make hail damage more likely, insurers were concerned that policyholders might exploit insurance to their own benefit, particularly through insuring only the more vulnerable crops on their land and an intentional underinsurance of their crops. In summer 1846, the Royal Famers disallowed claims from farmers where the quantity of produce had exceeded the rules of the maximum allowance under the insurance. ${ }^{117}$ Underinsurance of crops was a business risk that they were not prepared to tolerate and the valuer's field visi ts here became crucial. For instance, it was Mr Rogerson's visit to Elmham in Norfolk that disallowed a valued loss of $£ 7: 4: 0$ because there was still as much crop left in the field as had been damaged by hail. ${ }^{118}$ To a Mrs Rebecca Carter of Essex, the board decided that: "it appearing that the insurer having underinsured her crops, she was not entitled to any remuneration, none was therefore allowed." ${ }^{119}$ Mrs Carter contested part of this decision and was allowed some compensation. ${ }^{120}$ The insurance business followed strict adherence to policy rules and at the same time had a degree of flexibility about

\footnotetext{
115 Royal Farmers, Correspondence from John Reddish to the Royal Farmers Board of Directors, March 30 1861, copied into the Royal Farmers Board Report 1861, MS14991.

116 Alborn, "Regulated lives."

117 Royal Farmers, Minute book 7, 1845-1846, MS14989/007.

118 Ibid.

119 Royal Farmers, Minute book 8, 1846-1847, MS14989/008. This is one of the few female policyholders we have uncovered.

${ }^{120}$ Royal Farmers, Minute book 9, 1847-1848, MS14989/009.
} 
whether and when those rules would apply. Managing reputation, keeping cases out of the court room, and retaining customers' loyalty were all factors in shaping how insurers responded to individual requests.

We can now see that agents and valuers were a source of fragilities in the operation of a hail insurance business. Enforcing rules and paperwork enabled the head office to govern at a distance, but always provisionally, subject to further tinkering as needs arose. We asked what hail risk constituted, at the end of section $3 b$, and part of the answer is therefore that claims were to some extent shaped by agents and valuers. Nonetheless, the geography of hail risk was considered too, but not in isolation from the agents.

\section{Pricing risk}

In 1852, the County AGM records the first signs of a broader questioning of the geographical variability of hail risk. ${ }^{121}$ In their view, recent years had seen a greater frequency of hail sto rms and they worried that the climate might be changing with a resulting change in the distribution of risk: "hail storms in this country appear to have become much more frequent and destructive every year, and that districts which for many years were never visited by such calamities, have latterly suffered as much as those which, from their exposed situations, have generally been considered more liable to hail storms." ${ }^{122}$ Despite an interest in changing patterns of hail risk, there is no evidence hail insurers used weather forecasts or almanacs in their operations; indeed, we have argued elsewhere that while they created their own informal hail knowledge, they neither sought explanations nor scientific engagement. ${ }^{123}$ Indeed we noted earlier that it was this recent experience that led the County to conform to the agreed rates of their rivals, even though the ir actual loss figures do not

\footnotetext{
${ }^{121}$ County, $4^{\text {th }}$ Annual General Meeting report, February $41852, B 407,7242 / 2$.

122 Ibid.

${ }^{123}$ Kneale and Randalls, "Invisible atmos pheric knowledges," 40-41.
} 
support this season being particularly severe. From at least the mid-1850s, the companies guaranteed the risks of large crop policies with their rivals to spread their exposure. ${ }^{124}$ The geographies of hail represented a collective threat to the insurers.

It was one area in particular that attracted most attention and, probably not coincidentally, it was the same area as Mr Swan's Cambridge agency. Reddish, as we know, was well aware of the risks of this agency, but in the early 1860s it became about more than just one agency. In January 1862 Chesshyre wrote to Royal Farmers to enquire about the losses they were experiencing in Cambridgeshire and Huntingdonshire. ${ }^{125} \mathrm{He}$ had corresponded with Gilman, from the General, and Hanson, from the Midland, and suggested a more general inspection of the loss books in these areas, desiring to expand the guarantee of risks in these areas. ${ }^{126}$ This area attracted further attention in 1866 when after a couple of years of lower prices Royal Farmers decided to decline 4d rates for white straw crops in a defined geographical area -12 miles radius from Somersham railway station. ${ }^{127}$ They adopted new $8 \mathrm{~d}$ rates for the area. While they agreed that risks were higher in this area they did not specifically identify a cause - whether it was to do with hail risks, crop risks or other factors, though there is some consensus that the choice of crops played a part.

This geographical area catalysed a series of disagreements between the different hail insurers, which at times became quite personal and bitter. Indeed, the not-fully-understood dangerousness of a commercially valuable area undermined any attempts to reconstitu te agreed pricing. In 1868, Reddish noted with frustration that agreed rates had to be abandoned with each office setting independent rates. ${ }^{128}$ Part of the failure resulted from a lack of information sharing. Despite the efforts of 1862, by 1868 Gilman refused to share premium and loss data from the General, while

\footnotetext{
124 Royal Farmers, Minute book 15a, 1855-1859, MS14989/015.

125 Reported in Royal Farmers, Minute book 15b, 1859-1864, MS14989/016.

126 Ibid.

127 Royal Farmers, Board Report, March 6 1866, MS14991,

128 Royal Farmers, Board Report, March 2 1868, MS14991.
} 
Chesshyre failed to divulge even the County's averages. ${ }^{129}$ The General were happy to agree to a special rate, but the County refused to entertain any additional rates for peas and beans in that district with Chesshyre arguing "that when taken with white straw it is only reasonable that good and bad should go together." ${ }^{130}$ Reddish's calculative rational ism bemoaned such a path stating with obvious irritation that "all I said was useless." ${ }^{131}$ Peas and beans were more dangerous than straw for both individuals, but Chesshyre's ideal of insurance as an equal protector of all no matter how good the risk or loss ratio, clashed with Reddish's desire for risk-based pricing.

Even Gilman's special rate differed from Royal Farmers, initially having a two-fold distinction, treating the whole of the counties of Cambridgeshire and Huntingdonshire at a special rate, and the 12 mile radius from Somersham with even higher rates. ${ }^{132}$ In the mid-1870s the General established a new radius of 10 miles from St Ives with the boundaries dictated by roads and rivers rather than a 12 mile concentric ring. ${ }^{133}$ These different geographies of risk were hard to fathom given the refusal to share data about the dangerousness of these places. As the hail insurance premiums begun to decline in the wake of broader agricultural economic changes, not least the declining wheat prices and move from arable to livestock farming, ${ }^{134}$ and the Midland stopped playing a significant role, ${ }^{135}$ the strained personal relations between the three largest remaining insurers hindered any effort to form a collective response. Gilman took umbrage at travelling to meet Chesshyre and finding him away; ${ }^{136}$ Chessyre considered Gilman's approach to pricing to be "mischievous"; ${ }^{137}$ and Reddish considered Chesshyre's ideal to accept the bad with the good irrational in terms of business logic. ${ }^{138}$

\footnotetext{
129 Ibid.

130 Ibid.

131 Ibid.

132 Ibid.

133 Royal Farmers, Board Report, February 15 1875, MS14991.

134 Hunt and Pam, "Prices and structural response."

135 Royal Farmers, Board Report, March 7 1871, MS14991.

${ }^{136}$ Royal Farmers, Board Report, March 21 1871, MS14991.

137 Royal Farmers, Board Report, March 2 1875, MS14991.

138 Royal Farmers, Board Report, March 5 1872, MS14991.
} 
Reddish complained that the whole situation was "absurd"139 and reflecting in 1884 he felt that the constant pricing changes was a real "source of regret" given this was an industry in decline. ${ }^{140}$

Pricing hail risk involved a calculative assessment of risk, but one drawn on company experience rather than any collaborative sense of industry understandings -indeed after the mid-1860s it appears that companies refused to share commercially valuable data. The hail business was an intensely geographical enterprise, with local risks, local agents and valuers, and with insurers that had a keen sense of geographical variability. Yet rather than that variability enabling an actuarial approach to risk as in life assurance, it led to secrecy, competition, and personal rivalries that condemned the collective spirit of the hail insurance business at the worst possible time. It is impossible to say how much of the decline was caused by internal industry rivalries as opposed to broader economic changes, but we can argue that both coincided in a damaging way. Pricing and managing risks was anything but easy for hail insurers, and fragile achievements of information sharing and agreed pricing fell apart in the face of extraordinary risks in 'a dangerous area'.

\section{Conclusions}

Hail insurance emerged as a product to insure crops, particularly arable crops, against the effects of hail storms. Established through a network of agricultural actors, from prominent experts and industrialists who regularly met in the head offices of the insurance companies, to a network of agents in market towns that sold and managed contracts on behalf of the farmers in their local areas. With a diffused network, hail insurers faced a situation of rather fragile power in that while they attempted to retain control through formal procedures and rules, standardised paperwork that agents and farmers should stick to, they could not fully control these. Farmers, agents and valuers at

\footnotetext{
139 Royal Farmers, Board Report, March 2 1875, MS14991.

140 Correspondence from John Reddish to the Directors, 1884, Royal Farmers, in lieu of a Board Report, MS14991.
} 
various times intentionally and unintentionally broke the rules and at least sometimes got away with it. The late 1850 s into the early 1870 s proved to be the heyday of hail insurance in terms of the amount of premiums collected. With wheat prices high and arable farming at seemingly record productivity, hail insurers were generally positive about the future of the business that seemed to becoming stabilised as a core business risk management product.

From the 1870s, however, the hail insurance business went into steady decline with premiums falling on a year-by-year basis across all companies (Figure 1). The board of the Royal Farmers blamed this on the declining acreage of arable crops and the switch to pasture. ${ }^{141}$ Indeed Reddish reported in 1884 that he thought it difficult for the hail business to grow again given the changing agricultural economic context-the best they could hope for was to hold their own in terms of the share of the remaining market. ${ }^{142}$ It was not only farmers, but agents that were becoming harder to find too. Shareholders of the company were increasingly living in towns and were therefore less likely to be or know well-networked farming agents to represent the business. ${ }^{143}$ In 1888 the Royal Farmers business was absorbed into the Alliance British and Foreign Fire and Life Assurance Company and by 1901 Royal Farmers hail premiums were down to just $£ 1,215$ for the entire year (Figure 1), although it is not clear exactly when they stopped issuing hail policies. It was not only Royal Farmers in decline. In 1892 the County called an extraordinary AGM on Wednesday $10^{\text {th }}$ August to resolve to voluntarily wind up the company. ${ }^{144}$ With historical irony given the personal rival ries that had developed, the General purchased their rival, taking on their policy books and expenses along with their remaining agent network. In fact, the only exception to the story of decline was the General. Absorbing its competitors and seeing the remainder go into perpetual decline, the General managed to increase premiums from $f 6,716$ in 1897 to $f 10,119$ in 1907,

\footnotetext{
${ }^{141}$ Royal Farmers, Board Report, March 6 1877, MS14991.

142 Correspondence from John Reddish to the Directors, 1884, Royal Farmers, in lieu of a Board Report, MS14991.

143 Ibid.

144 County, Provisional agreement of County Hail Storm Insurance and directors of General Hail Storm Insurance Society, Norwich, 1892, B413, 7265.
} 
maintaining premiums of between $£ 8,000$ and 18,000 for the first two decades of the $20^{\text {th }}$ century. ${ }^{145}$ Hail subsequently became a subsidiary product from the mid-1920s, to be sold only in combination with other insurance products, but with increasing profitability again in the later 1930s, the General, along with new competitors, started selling it more wi dely. ${ }^{146}$ Hail insurance is still sold today.

Hail insurers in the 1850s likely imagined their business to be at the heart of the booming wheat economy acting in consort with farmers business needs; twenty years later, such a vision looked outdated. As we have argued, however, the story of hail insurance offers far more than just a microcosm of a grander economic narrative. Hail insurance's prosperity and decline owed as much to farmers, agents, valuers, paperwork, hail storms, and personal rivalries as it did the broader structural economic changes. This provides a livelier narrative enabling us to see the micro-power relations that shaped agricultural insurance practice in this period and the continual contingency that the hail business faced.

Conceptualising this emerging insurance business as a fragile network is a useful device for enabling us to both understand the way the central insurance office tried to govern this network of actors at a distance, while reminding us that this was always incomplete and provisional -the network of actors held together in one configuration could swiftly break down or alter as actors from farmers to agents, and paperwork to insurers engaged in personal rival ries, challenged existing configurations. The central insurance office did not retain all the power, but their actions had effects, at least if farmers or agents wished to remain part of the network.

\footnotetext{
145 General, Premiums and Losses, General Hailstorm Insurance Company, 1873-1946, NU294.

${ }^{146}$ The General sent letters to agents from 1926 instructing them to no longer sell standalone hail products and then reversed this policy by 1939. General, Letter to the District Managers at the Grimsby, Lincoln, Northampton and Nottingham offices, December 2 1926, MN5393. General, Letter to Yorkshire Insurance Company, March 17 1939, MN5392. More research is required to trace the development of hail insurance in the mid-20th century, but for instance the General (Norwich Union), Yorkshire Insurance Compa ny and the National Farmers Union agreed rates during the early 1940s, General, Letter from Yorkshire Insurance Company to the Norwich Union, February 5 1943, NV5399.
} 


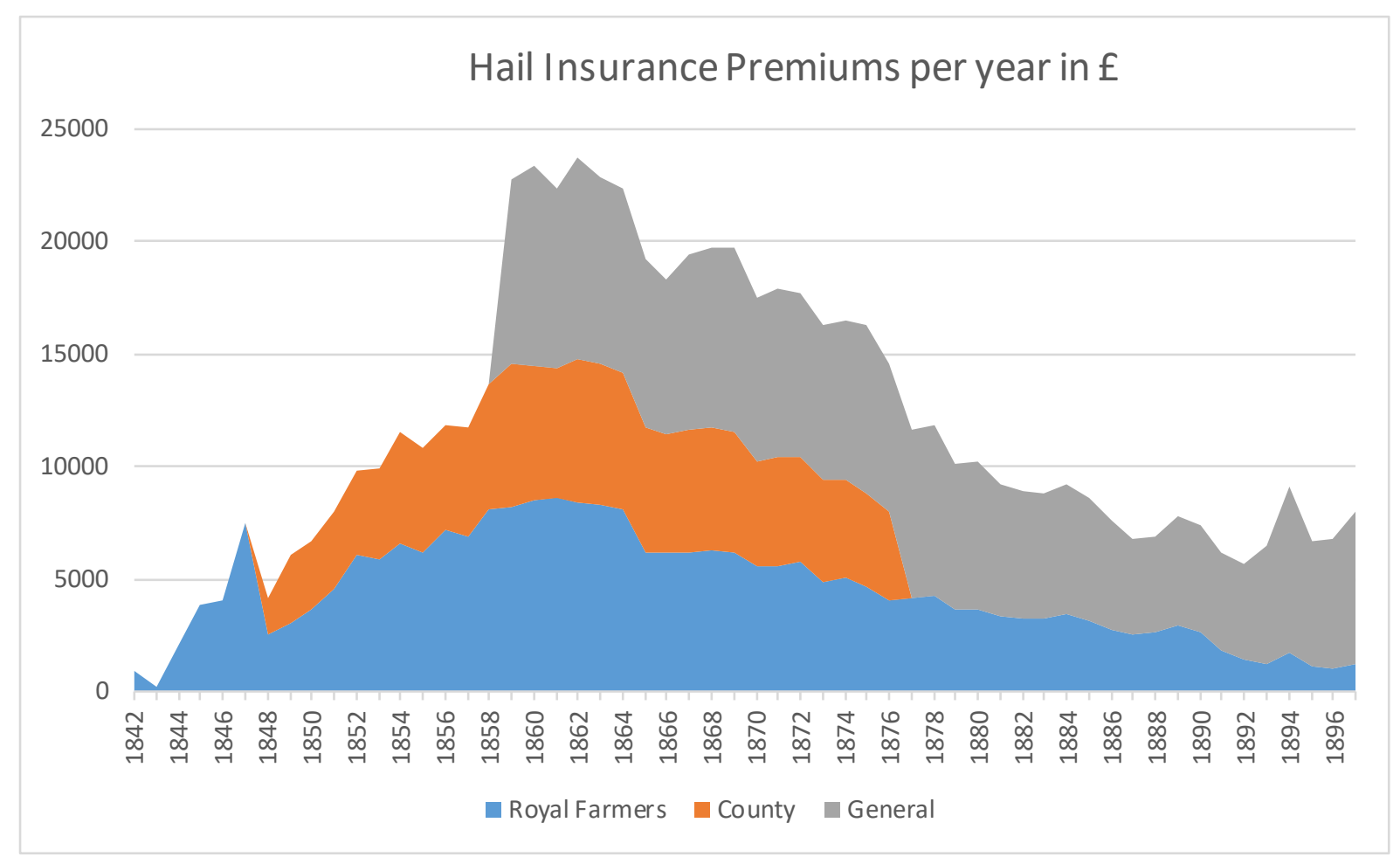

Figure 1. Premiums as recorded in each company's account books, except for the County in 1855 and 1857, and Royal Farmers 1842-1848. ${ }^{147}$ A smoothed average has been used to interpolate data for the County in 1873 and 1875.

147 This data is from Stead, "Risk and risk management," 343. 


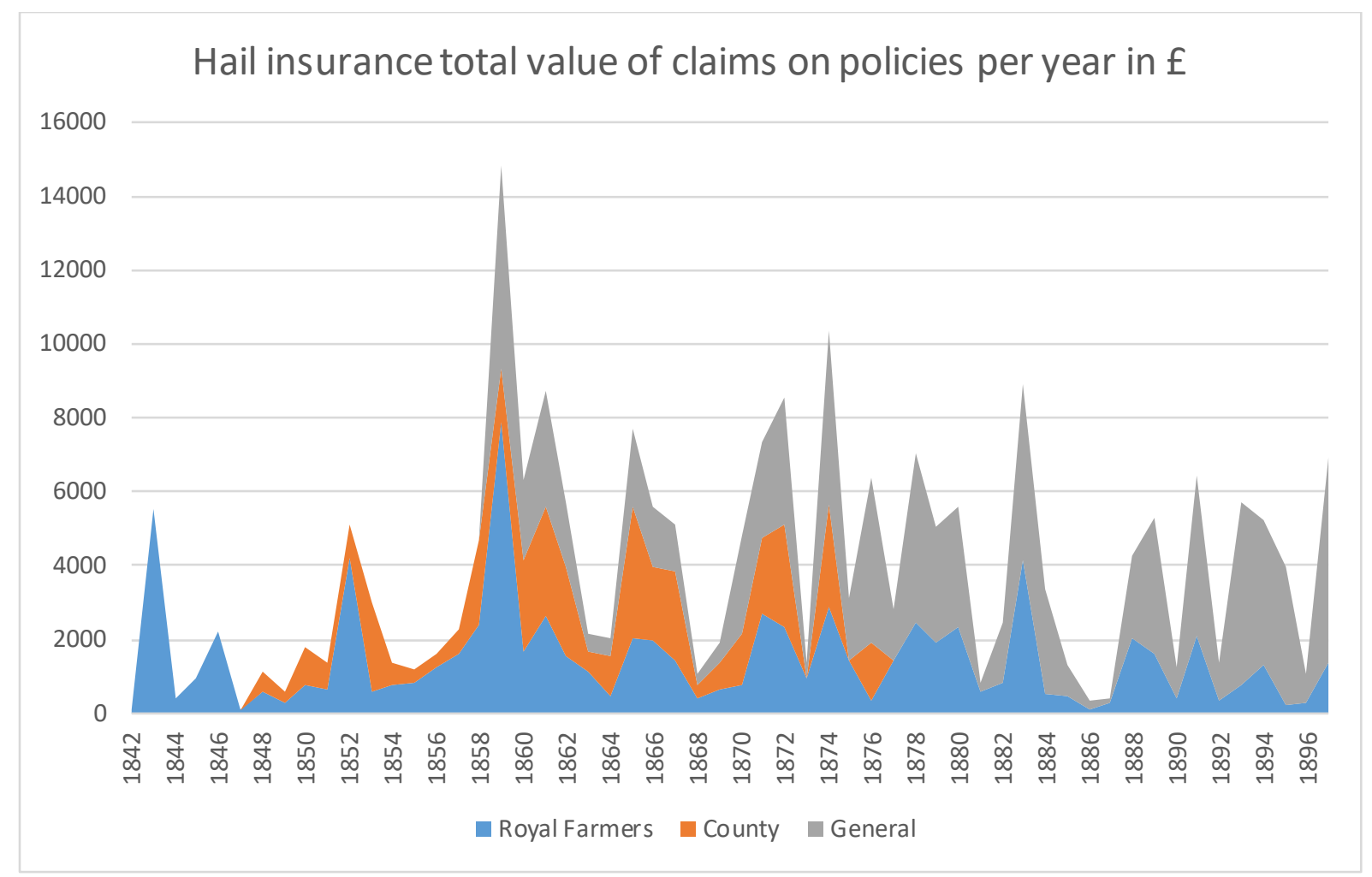

Figure 2. The value of claims on policies as recorded in each company's account books for the periods in which such records are available, except for the County in 1855 and 1857, and Royal Farmers $1842-1848 .^{148}$

148 This data is from Stead, "Risk and risk management," 343. 


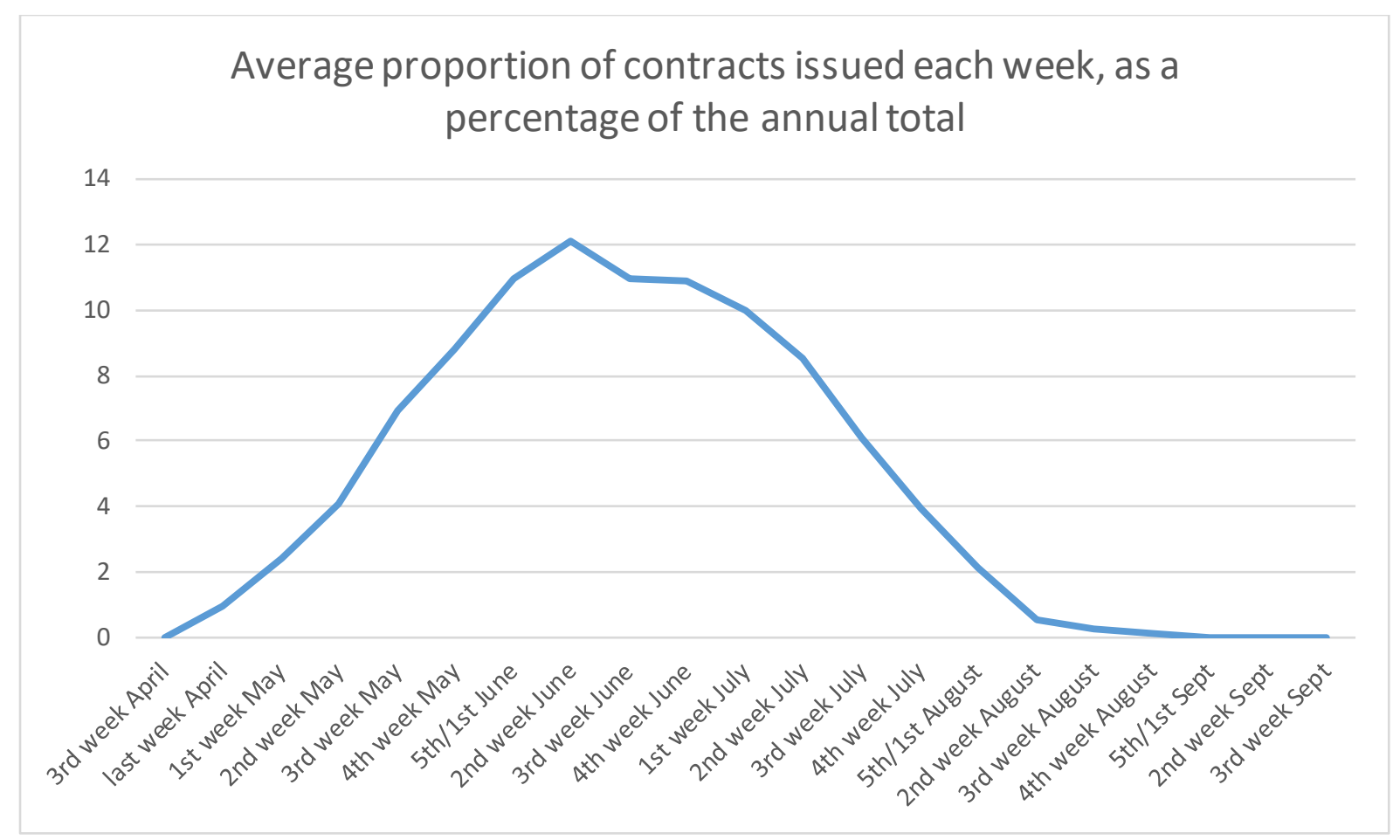

Figure 3. Royal Farmers averaged data detailing the $\%$ of contracts issued each week across 10 hail seasons, 1846-1855, smoothed via averaging the differences between weeks. After 1855, Royal Farmers stopped recording the weekly confirmation of issue of policies at its meetings. ${ }^{149}$

\begin{tabular}{|l|l|l|l|}
\hline Company Name & Head office & Year formed & Year ended \\
\hline Royal Farmers & London & 1839 & 1888 but issued hail \\
& & & policies untilat least \\
& & & Absor. \\
& & & Alliance British and \\
& & Foreign Fire and Life \\
& & 1843 & Assurance Company \\
\hline General & Norwich & 1898 \\
\hline
\end{tabular}

${ }^{149}$ Royal Farmers, Minute books 7-14, MS14989/007-014. 


\begin{tabular}{|c|c|c|c|}
\hline & & & $\begin{array}{l}\text { Absorbed into the } \\
\text { Norwich and London } \\
\text { Accident Insurance } \\
\text { Association }\end{array}$ \\
\hline $\begin{array}{l}\text { Agricultural Hail } \\
\text { Company }\end{array}$ & Unknown & 1845 & $\begin{array}{l}\text { Unknown. } \\
\text { The only record of this } \\
\text { company is a note in } \\
\text { Reddish's review of } \\
\text { the hail business in } \\
1861 \text {. }\end{array}$ \\
\hline County & Hertford & 1847 & $\begin{array}{l}1892 \\
\text { Absorbed into the } \\
\text { General }\end{array}$ \\
\hline $\begin{array}{l}\text { London and County } \\
\text { Hail and Cattle } \\
\text { Insurance Company }\end{array}$ & London & 1854 & $\begin{array}{l}1859 \\
\text { Hail business } \\
\text { absorbed into the } \\
\text { General }\end{array}$ \\
\hline Midland Counties & Lincoln & 1855 & $\begin{array}{l}\text { c.1892 } \\
\text { It is unclear when they } \\
\text { stopped issuing hail } \\
\text { contracts, but Reddish } \\
\text { dismissed them as a } \\
\text { serious rival in } 1871\end{array}$ \\
\hline
\end{tabular}




\begin{tabular}{|c|c|c|c|}
\hline $\begin{array}{l}\text { National Economic } \\
\text { Hail Storm Assurance } \\
\text { Company }\end{array}$ & Norfolk & 1855 & $\begin{array}{l}1857 \\
\text { Absorbed into the } \\
\text { General }\end{array}$ \\
\hline $\begin{array}{l}\text { World Insurance } \\
\text { Company, Hail Storm } \\
\text { Department }\end{array}$ & London & 1858 & $\begin{array}{l}\text { c.1864 } \\
\text { The World Insurance } \\
\text { Company offered hail } \\
\text { policies according to } \\
\text { Reddish. In c.1864 the } \\
\text { business was wound } \\
\text { up and transferred to } \\
\text { the City and County } \\
\text { Assurance Company. }\end{array}$ \\
\hline $\begin{array}{l}\text { Equitable Hail } \\
\text { Insurance Company }\end{array}$ & Norwich & 1865 & $\begin{array}{l}1867 \\
\text { Absorbed into the } \\
\text { General }\end{array}$ \\
\hline $\begin{array}{l}\text { Provincial Hail } \\
\text { Insurance Company }\end{array}$ & Winchester & 1872 & $\begin{array}{l}\text { Dissolved c. } 1916 . \\
\text { Although Reddish was } \\
\text { concerned by their } \\
\text { emergence, there is } \\
\text { very little subsequent } \\
\text { correspondence about } \\
\text { them. }\end{array}$ \\
\hline
\end{tabular}


Table 1. A list of the names and dates of known British hail insurance companies in the nineteenth century. ${ }^{150}$

\section{Bibliography of works cited}

Books

Alborn, Timothy. Regulated lives: Life assurance and British society, 1800-1914, Toronto: University of Toronto Press, 2009.

Anderson. Katherine. Predicting the weather: Victorians and the science of meteorology, Chicago, IL: University of Chicago Press, 2005.

Baker, Bruce E. and Barbara Hahn. The cotton kings: Capitalism and corruption in turn-of-the-century New York and New Orleans, New York: Oxford University Press, 2016.

Bouk, Dan. How our days became numbered: Risk and the rise of the statistical individual, Chicago, IL: University of Chicago Press, 2015.

Capris di Cigliero, Saverio. Saggio sullo Stabilimento d'una Cassa d'Assicurazione Mutua contro danni cagionatidalla Grandine. Torino: salla Tipografia di Domenico Pane, 1830.

Cockerell, Hugh A.L. and Edwin Green. The British insurance business: history and archive, Sheffield: Sheffield Academic Press, 1994.

\footnotetext{
${ }^{150}$ With thanks to Anna Stone at Aviva for providing information on the history of the General. Another important source is Royal Farmers, Corres pondence from John Reddish to the Royal Farmers Board of Directors, March 30 1861, copied into the Royal Farmers Board Report 1861, MS14991. Other sources include National Archives company registration records and news paper adverts. Reddish warned of the emergence of the rival Provincial in Royal Farmers, Board Report, March 5 1872, MS14991. Information about the World Insurance Company was garnered from an agent's advert in Wrexham and Denbighshire Advertiser, August 6 1859, VL, 257, and the notice of transferral of life policies in the London Standard, August $21864,12474$.
} 
De Goede, Marieke. Virtue, fortune and faith: A genealogy offinance, Minneapolis: University of Minnesota Press, 2005.

Joyce, Patrick. The state of freedom: a social history of the British state since 1800, New York: Cambridge University Press, 2013.

Latour, Bruno. Science in action: How to follow scientists and engineers through society, Cambridge, MA: Harvard University Press, 1987.

Levy, Jonathan. Freaks of fortune: The emerging world of capitalism and risk in America, Cambridge, MA: Harvard University Press, 2012.

Lobo-Guerrero, Luis. Insuring security: Biopolitics, security and risk, Abingdon: Routledge, 2011.Porter, Theodore M. Trust in Numbers: The pursuit of objectivity in science and public life, Princeton, NJ: Princeton University Press, 1995.

Zakim, Michael. Accounting for capitalism: The world the clerk made, Chicago, IL: University of Chicago Press, 2018.

Articles, Chapters in Books

Baker, Alan R.H. "Hail as hazard: changing attitudes to crop protection against hail damage in France, 1815-1914," The Agricultural History Review, 60 (2014): 19-36.

Clarke, Ernest. "Shaw, William (1797-1853)," rev. Nicholas Goddard, Oxford Dictionary of National Biography, Oxford University Press, 2004 [http://www.oxforddnb.com/view/article/25272, accessed 3 Feb 2014]

Cox, Graham, Philip Lowe and Michael Winter. "The origins and early development of the National Farmers' Union," The Agricultural History Review, 39 (1991): 30-47. 
Didier, Emmanuel. "Sampling and democracy: representatives in the first United States surveys," Science in Context, 15 (2002): 427-445.

Didier, Emmanuel. "Do statistics 'perform' the economy?" in Do economists make markets? On the performativity of economists, ed. Donald MacKenzie, Fabian Muniesa and Lucia Siu. Princeton, NJ: Princeton UniversityPress, 2007, 276-310.

Goddard, Nicholas. "The development and influence of agricultural periodicals and newspapers, 1780-1880," The Agricultural History Review, 31 (1983): 116-131.

Grigg, David. "Farm size in England and Wales, from early Victorian times to present," The Agricultural History Review, 35 (1987): 179-189.

Hull, Matthew S. "Documents and bureaucracy," Annual Review of Anthropology, 41(2012): 251267.

Hunt, E.H. and S.J. Pam. "Prices and structural response in English agriculture, 1873-1896," Economic History Review, L (1997): 477-505.

Hunt, E.H. and S.J. Pam. "Managerial failure in late Victorian Britain?: land use and English agriculture," Economic History Review, LIV (2001): 240-266.

Hunt, E.H. and S.J. Pam. “Responding to agricultural depression, 1873-96: Managerial success, entrepreneurial failure?," The Agricultural History Review, 50 (2002): 225-252.

Kneale, James and Samuel Randalls. "Invisible atmospheric knowledges in British insurance companies, 1830-1914," History of Meteorology, 6(2014): 35-52.

Kneale, James and Samuel Randalls. "Imagined geographies of climate and race in Anglophone life assurance, c.1840-1930," in Weather, climate, and the geographicalimagination: placing atmospheric knowledges, ed. Martin Mahony and Samuel Randalls, Pittsburgh: University of Pittsburgh Press, 2020, 115-131. 
Law, John and Evelyn Ruppert. "The social life of methods: devices," Journal of Cultural Economy, 6 (2013): 229-240.

Matthews, Stephen. "Cattle clubs, insurance and plague in the mid-nineteenth century," Agricultural History Review, 53 (2005): 192-211.

Mauelshagen, Franz. "Sharing the risk of hail: Insurance, reinsurance and the variability of hailstorms in Switzerland, 1880-1932," Environment and History, 17 (2011): 171-191.

McCloskey, Donald N. “The open fields of England: rent, risk, and the rate of interest, 1300-1815," in Markets in History: Economic Studies of the Past, ed. David W. Galenson, Cambridge: Cambridge University Press, 1989, 5-51.

Miskell, Louise. "Putting on a show: the Royal Agricultural Society of England and the Victorian town, c.1840-1876," The Agricultural History Review, 60 (2012): 37-59.

Musson, A.E. "The Great Depression in Britain, 1873 to 1896: A reappraisal," The Journal of Economic History, 19 (1959): 199-228.

Oberholzner, Frank. "From an Act of God to an Insurable Risk: The Change in the Perception of Hailstorms and Thunderstorms since the Early Modern Period," Environment and History, 17 (2011): $133-152$.

O’Malley, Pat and Alex Roberts. “Governmental conditions for the economization of uncertainty: Fire insurance, regulation and insurance actuarialism," Journal of CulturalEconomy, 7 (2014): 253-272.

Pearson, Robin. "Towards an historical model of services innovation: the case of the insurance industry, 1700-1914," Economic History Review, 50 (1997): 235-256.

Perry, P.J. "High farming in Victorian Britain: The financial foundations," Agricultural History, 52 (1978): 364-379. 
Pietruska, Jamie L. “'Cotton guessers': Crop forecasters and the rationalization of uncertainty in American cotton markets, 1890-1905," in The rise of marketing and market research, ed. Hartmut Berghoff, Philip Scranton and Uwe Spiekermann, New York: Palgrave Macmillan, 2012, 49-72.

Rose, Nikolas and Peter Miller. "Political power beyond the State: problematics of government," The British Journalof Sociology, 43 (1992): 173-205.

Stead, David R. "Risk and risk management in English agriculture, c.1750-1850," Economic History Review, LVII (2004): 334-361.

Turner, Michael. “Output and prices in U.K. agriculture, 1867-1914, and the Great Agricultural Depression reconsidered," The Agricultural History Review, 40 (1992): 38-51.

Webb, Jonathan D.C. and Derek M. Elsom. "The great hailstorm of August 1843: The severest recorded in Britain?," Weather, 49 (August 1994): 266-273.

Newspaperand Magazines

Illustrated London News

London Standard

The Leicester Chronicle

The Standard

Trewman's Exeter Flying Post

Wrexham and Denbighshire Advertiser

Archives

Royal Farmers Insurance company archive, London Metropolitan Archives, London 
County Hail Storm Insurance company archive, Hertfordshire County Council Archives, Hertford

General Hailstorm company archive, Aviva, Norwich 